Produto \& Produção, vol. 13 n. 2, p. 77-94, jun. 2012

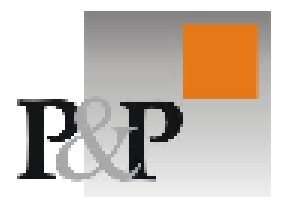

\title{
Associating collaboration with active learning: an experience in an industrial engineering course
}

Recebido em 20/04/2011. Aceito em 06/03/2012.

\section{Breno Barros Telles do Carmo}

Departamento de Ciências Ambientais e Tecnológicas

Universidade Federal do Ceará -UFC

brenobarros@ufersa.edu.br

\section{Renata Lopes Jaguaribe Pontes \\ Pesquisadora do Instituto UFC Virtual \\ renata@virtual.ufc.br}

The Internet changed the way of learning, promoting interactivity and autonomy. Through Web 2.0, many tools can be used to establish strategies in order to motivate students for autonomous learning. This paper presents an analysis of such strategies applied to an industrial engineering course. It discusses an application in an Organizational Productive Arrangement (OPA) course using web tools to promote autonomous learning using an active strategic methodology. Two tools are used: a blog to promote interaction and a wiki to motivate research and collaboration. An information system is used to support the active strategic methodology. A survey of 40 students has been conducted; the data are presented and discussed.

Keywords: Cooperative learning; web 2.0; Active learning.

A Internet modificou a forma de aprender, incentivando a aprendizagem pela interação e a autonomia. Através da Web 2.0, muitas ferramentas podem ser utilizadas como ferramentas dentro de estratégias de ensino que motivem os alunos para uma aprendizagem mais autônoma. Este artigo apresenta uma análise da aplicação destas ferramentas em um curso de Engenharia de Produção. Discute-se a aplicação/resultados obtidos com a utilização das ferramentas da Web 2.0 na disciplina de Arranjos Produtivos Organizacionais com o objetivo de fomentar uma aprendizagem mais autônoma por parte dos alunos. Duas ferramentas foram utilizadas: Blog e Wiki. O primeiro foi utilizado para promover interação e o segundo para promover pesquisa e colaboração. Um sistema de informação foi utilizado para suportar a atividade proposta aos discentes. Foi realizada uma pesquisa com 40 estudantes. Os resultados são apresentados e discutidos.

Palavras-chave: Aprendizagem cooperativa; Web 2.0; Autonomia. 


\section{INTRODUCTION}

Vanasupa et al (2009) see a challenge for Engineering courses to train engineers with quick information assimilation. This is an important characteristic because globalization brings the necessity for enterprises to innovate their products, processes and management to be competitive. This dynamic is improved by information and communication technologies. Online tools promote an interaction development and the information is disseminated very quickly.

Students' expectations in classroom dynamics have been modified during this time. It has been observed that engineering students who get into the university are more focused on technology. It is very hard for professors to share attention with these technological tools. Today, many engineering students have a computer and they can access the internet. In many cases, they go to classroom with their computers.

In these cases, several times, online information may be more attractive than the contents presented by the professor. There are two reasons for this to happen: monotone strategy and non-applied knowledge. A way to solve this problem is to articulate the class subject with these technological tools. So, it is necessary to combine planned activities with these two components (HOLVIKIVI, 2007). This paper will discuss students and professors' adaptation to Information and Communication Technologies.

On the other hand, Estes et al (2005) define that it is important to professors to attempt to understand how students learn. It is very important, but they need to observe how their students think and which technological tools they use. With these two elements, professors can propose activities to promote students motivation, the mainspring in learning process proposed by Vanasupa et al (2009).

It is hard for professors to dominate all these tools because they were not trained to develop their pedagogical practice using them. It is a challenge to motivate this group to use these other kinds of tools if they do not know how to use them.

There are many tools that are now available with internet widespread use. One of them are focused on cooperation and collaboration. It is called Web 2.0. Inside this group, two tools will be discussed in this research - the Blog and Wiki. It will be presented examples of these tools applications to engineers' learning.

Nowadays, the blogs have been being used in many countries for news and promoting discussions. Some examples can be given like the blog created to inform about war against trafficking in Rio de Janeiro, in 2010. When this kind of information is socialized, it can be formed a discussion space, aiming to understand this phenomenon. Based on this potential, blogs can be used in education to promote this discussion space and socialize knowledge developed by students, making it available to the society.

Another challenge for engineering formation results from "non-application knowledge" that makes the classroom like a space where the topics are not applied to future professional practice. To solve this problem, active strategies must be proposed to motivate students to the importance of the concepts presented in classroom. It is important to associate technology and subject application. These two ideas, as connected, can promote a motivational learning atmosphere, a hypotheses defended in this experimental research.

Accordingly, an important question is discussed in this paper: how active and collaborative strategies can be used together to promote students' motivation? 
Looking at these challenges, this paper's objective is to explain how TICs can be associated to applicable knowledge to be used for teaching engineering. Specifically, we want to demonstrate a successful case of the use of blog and wiki associated to an information system - SIMAP, in Organizational Productive Arrangement (OPA) course, inside an Industrial Engineering course.

The structure of this paper follows some steps. The first one presents a theory that supports this research, discussing collaboration and active learning to promote autonomous learning. Afterward, it will be presented the model developed and applied in the study. Finally, there are the final remarks showing the benefits and challenges to be overcome.

\section{COLLABORATION PROMOTING MOTIVATION IN AUTONOMOUS LEARNING}

Nirmalakhandan et al (2007) see that the traditional teaching methods, based on textbooks -chalkboard - lecture - homework - test have been pointed out as inappropriate for learning. A modern concept in education is collaboration and active methods. These ideas put students in a different attitude in the education process, in which they must turn to construct their own ideas. This concept is shared by HmeloSilver et al (2007), who understand that all types of learning involve knowledge construction, like in a constructivist process. In this case, professors act like tutors and students present an autonomous behavior.

To reach this kind of construction, students must be motivated to learn. To construct their ideas, it is proposed discussions about themes suggested by professors. This discussion can generate a collaborative space, where each student can help others to construct their ideas. This is called collaboration. In this case, students must have a different reaction to the learning process, being more active and having a more participatory approach.

Methodologies must be thought out considering students like active elements in the learning process. This is not easy and can not be dissociated from environmental, cultural and historical characteristics (VANASUPA et al, 2009). These characteristics are defined as/in development domains and professors must organize their teaching strategies using this concept to motivate their students. Figure 1 shows this perspective. 


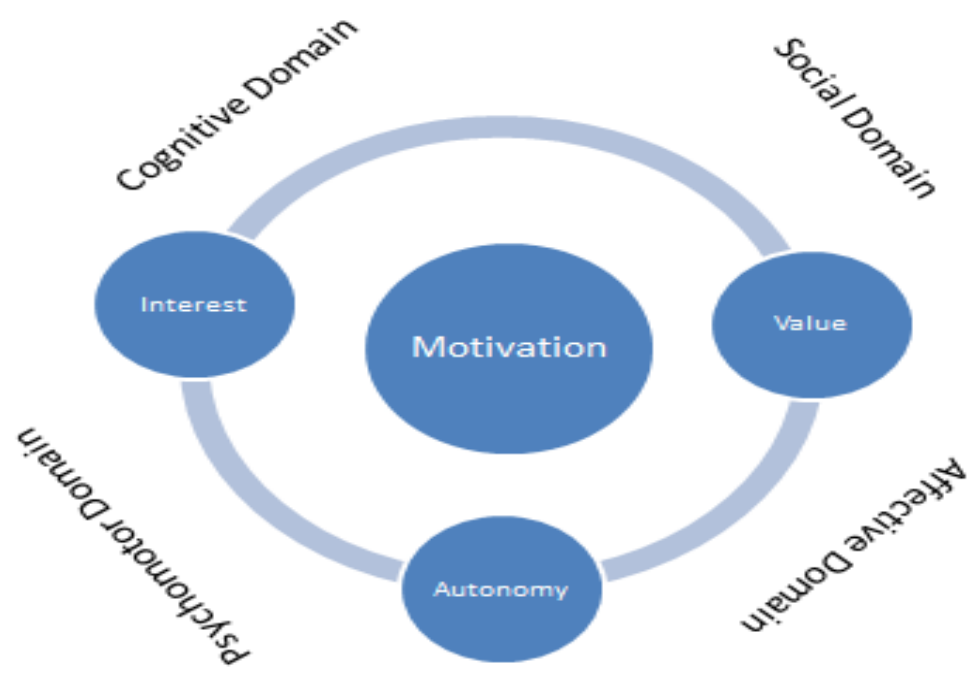

Figure 1 - 4DDD. From Vanasupa et al (2009)

In Figure 1, it can be observed that there are four development domains. In the first group, Cognitive and Psychomotor Domains are considered internal factors and they are related to the information process and abilities acquired with individual practices (VANASUPA et al, 2009). These factors are the focus of the traditional teaching models.

In the second group, Social and Affective Domains are considered external factors and they are related to interaction. These two domains are very important to acquire knowledge (VANASUPA et al, 2009; NUNES; SILVEIRA, 2008). These factors are the focus of the new professional market demand.

These four domains are related to some constructs, the interest (pleasure activity development), the value (understand the importance of the topic in student life) and autonomy (interest evolution, the student goes beyond professors' materials), as Vanasupa et al (2009) propose.

According to this concept, it is necessary to promote the student's motivation for the the learning process get succeeded. Some strategies can be used to promote learning. The first idea discussed in this paper is collaboration to promote learning. It is proposed because an activity inside the social and affective domains is focused on this paper.

Johnson (1999) sees cooperative/collaborative learning like a method that encourages students learning from each other. The same author confirms that cooperative learning promotes higher achievement, critical thinking, interpersonal skills and self-confidence. Cooperation can develop students' active position in this process, in which they need to construct their concepts and discuss with the professor and other classmates.

To understand this active position, it is necessary to understand the concept of active learning. Nirmalakhandan et al (2007) observe that these techniques engage students in higher-order critical thinking skills such as analysis, synthesis, and evaluation. This attitude improves the student's learning.

A problem that can be identified in this model is related to the student's personality. To promote collaboration and an active position, it requires that the students show their points of view. One fact observed in this study is that shy students may fell intimidated to expose their ideas. Similarly, some students are not orally fluent, but they can express opinions very well by writing. Professors need to 
evaluate their students in these two ways.

There are some tools called Information and Communication Technological Tools for the task. The next topic presents TICs tools and analyses how they can be used to support the teaching process for the students to effectively learn.

\section{INFORMATION AND COMMUNICATION TECHNOLOGICAL TOOLS (TICS)}

Estes et al (2005) see that technology is important to promote a quality teaching process, but it needs to be understood and appropriately used. The simple technology used does not guarantee an excellent learning.

The same authors identified that many technologies have been developed and used in many engineering classrooms. Some examples are given by these authors: viewgraph machine, opaque projector, copier machine, television set, calculator, and movie projectors. Other more modern examples are: presentation graphics such as PowerPoint, engineering software packages, computer-aided instruction software, electronic textbooks, spreadsheets, math packages, simulation software and digital photographs. All these tools have been being used but they are not focused on collaboration and interaction. They do not put students like active actors in the learning process, but they consider them passive actors.

To avoid this kind of attitude, other tools need to be used. It is what Web 2.0 tools promote. This kind of technology, like a blog or wiki, can be used in a scaffolding technique. Scaffolding teaching is any form of assistance from an instructor that helps the student's knowledge construction (LABRANCHE, 2006). The difference and advantage observed in Web 2.0 tools is that it is not only the instructor who helps this activity, but the other students, too.

The use of TICs tools in classroom needs to be thought in order to realize where their use will be done when the proposed activity ask for them. These tools can promote an active position in all kinds of students including the shy ones. In this paper, two Web 2.0 tools and one information system were used to promote the students' active strategy development. They are: wiki and the blog (Web 2.0 tools) and, SIMAP (benchmarking information system). Each tool will be explained below.

\subsection{Wiki Tool}

Wiki is an online tool and it allows any people to cooperate, using collective writing. The users can include, change, correct, complement or exclude texts in a simple way and it is easy and practical. A well-known example is wikipedia.com. In this site, all changes are saved and all historical changes are memorized. This characteristic allows changes that can be undone and the knowledge evolution can be accomplished.

Because of this characteristic, the wiki can be used associated with the collaboration learning and the constructivism concept as well as being applied in education and how it was used in this research. Coutinho and Junior (2007) characterize wiki application like a knowledge construction space developed by students from the same course. The same authors understand that it also can be used in student's work development. They can create a collective project and update 
it in a website.

Many possibilities can be thought about wiki application on education. Some of them are proposed by Santamaria \& Abraira (2006) and Shwart \& Cossarin (2004):

- $\quad$ Student's dynamics interaction and collaboration;

- $\quad$ Exchange ideas, create applications, propose work planning;

- $\quad$ Create glossary, dictionaries, texts, manuals, etc.;

- $\quad$ See all content changing historically allowing professors to evaluate the knowledge advances;

- $\quad$ Create collaborative knowledge structure, potentiating the learning communities' creation.

With all these applications, this paper works with the concept to create a glossary and observe the knowledge evolution by the professor. These two wiki applications are the research focus.

\subsection{The Blog}

Internet and its tools evolution enabled a new internet user phase in which everyone can be the author and its information producer. This phase is known like Web 2.0. An example of its evolution is the web-blog that means logbook.

The blog appears in the last 1990s and it was a logbook for thinking, reports, personal reflections share, but it required a programming knowledge. In 1999, it was created the web-blog services, like "Blogger"by "Google", for example. This system is free and it makes easier the web-blog practice dissemination.

Carvalho (2010) sees blogs like web pages chronologically organized like a diary. On this page, it is possible to post images, texts or other files. There are spaces to users' comments and the reader can discuss with the blog author. This kind of resource promotes interaction and collaboration between users. In this case, the readers are authors too, proposing their ideas and complementing a concept (PRIMO; RECUERO, 2003).

This characteristic allows interaction and collaboration, and because of that, blogs are being used in education. According to Gomes (2005), a blog can be thought like a pedagogical resource in some situations: professors;

Space to promote access to a specialized information posted by

- $\quad$ Portfolio from students experiences in developing their works;

- $\quad$ Space for interchange, collaboration and discussion.

Because of its applications, blogs can be used in many education contexts, including engineering teaching Professor can follow students' work evolution and propose some changes. The other students can do the same. This collaboration has the potential to make students' work better.

\subsection{SIMAP}

The last tool used in this study is not a Web 2.0 tool. It is an information system developed to do research in other project and adapted to educational using. This software is based on benchmarking concepts and evaluates the management 
tools application in enterprises from a productive arrangement. Using data collected from enterprises, the system generates graphs to be interpreted by students.

SIMAP was thought and structured in seven dimensions to analyze enterprises, which were joined by the correlated attributes. The enterprise which reaches a good performance in these areas is considered an excellence one. To define what is good and where the enterprises should be, it was identified a benchmarking. Carmo et al (2011) defined by the sub-systems evaluated by SIMAP:

- Integrated management systems: evaluates the best management practices used in enterprise. It comprises quality, environment, social responsibility systems, and occupational health and safety norms.

- Production management system: evaluates management tools application in production systems.

- Products development system: evaluates product development methodology used in the enterprise.

- Logistics system: evaluates logistics tools application in production systems.

enterprise.

Human Resource system: evaluates how employees are valued by the

- $\quad$ Financial system: evaluates enterprises' financial health and if they use tools in decision-making, like investment analysis and costs systems.

An important point is that students study all these tools during their industrial engineering course. If they get in these disciplines with some knowledge about them learning can be better. Another advantage to use this system like a teaching tool is that the students can get motivated because they can understand how they will work after their course.

These three tools presented together were used to promote collaboration with applied knowledge. The strategy used by professors was the desire to stimulate students' autonomous learning and it was planned to promote a collaborative and active work. The next topic presents the methodology used in this experiment.

\section{METHODOLOGY}

This research is an experience in Productive Arrangement course, a topic in the Industrial Engineering course in the Federal University of the Semiarid Region, in Brazil. It is a research on phenomenological elements which Thiry-Cherques (2006) defines like a phenomenon study's researcher reflection. In this case, it was aimed to understand how learning can be obtained by using Information and Communication Technologies tools (TICs) with applied knowledge strategies.

It was proposed an active work to students, in which they had to use the SIMAP tool. The results had to be discussed using Web 2.0 tools, like blog and wiki. This research was based on a qualitative method called Participant Observation, seen by Flick (2009) like a strategy that allies document analysis, interviews, participation, direct observation and introspection. The same author understands that the researcher must get into his research object like one of its elements, influencing what is observed and occasioned by his participation. Figure 2 suggests the steps followed in this research. 


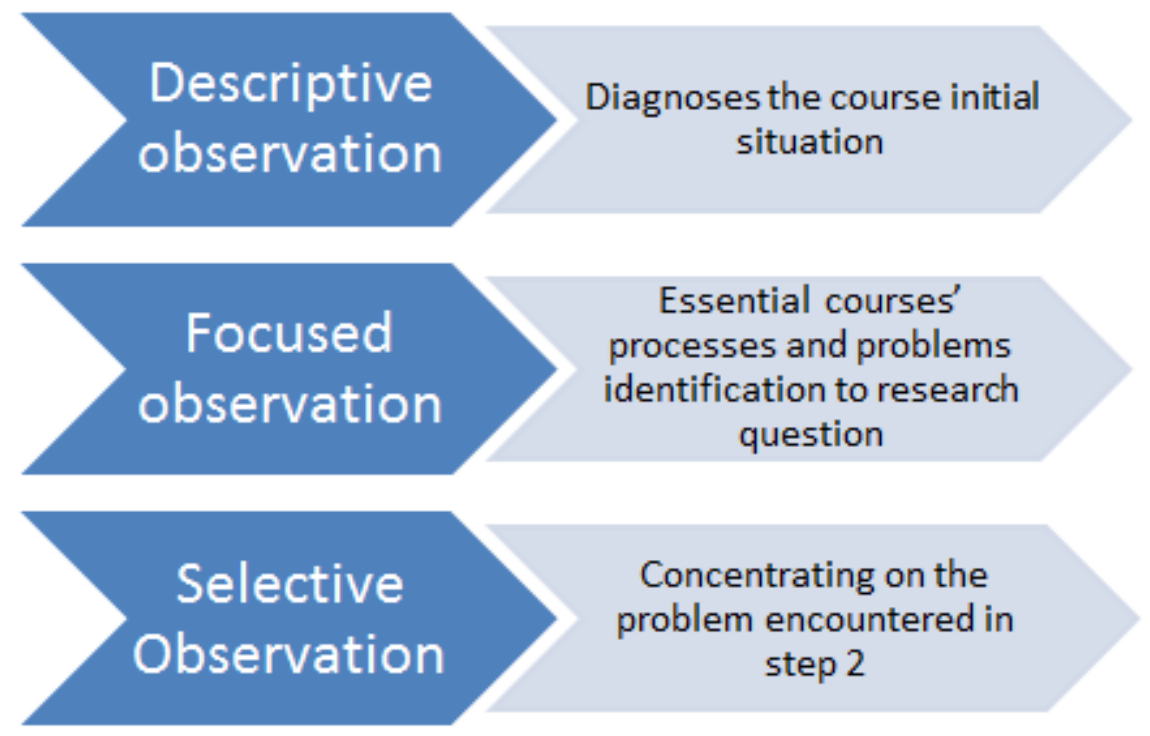

Figure 2 - Research method developed. From: Flick (2009).

In the first step, descriptive observation, the researcher and the professor prepared an activity for students to work in groups. He also began to prepare his field diary, which was produced after his classes. Looking at his appointments, he could observe students' passive attitude in their $1^{\text {st }}$ step work presentation. In this step, the objective was to observe how students understood the SIMAP concepts.

In the second step, focused observation, it was proposed that the TICs observe the students' predisposition to interaction and collaboration with the active activity proposed by the professor. In this case, a questionnaire was developed with specific tasks. The goal was to observe how students see the professor's attitude in the classroom and their interest to develop the work using the tools suggested.

In the third step, selective observation, a blog was created for students' work and experiences to be posted. In this case, the goal was to make the students learn each other and observe all the difficulties appointed by groups and promote interaction to solve these problems. This space to interaction was proposed to support students' final work presentation.

To evaluate the blog efficiency, a questionnaire was proposed with open and closed questions to evaluate the work like an interactive tool to promote the interaction, collaboration and autonomous learning.

\section{THE ACTIVE/COLLABORATIVE MODEL DEVELOPED}

This study was performed in the Organizational Productive Arrangement (OPA) topic in an Industrial Engineering graduation course. This topic is presented to students that are getting into Industrial Engineering courses in the Federal University of the Semiarid Region - UFERSA. In this case, the students did not know any concept in Industrial Engineering and have studied only math, physics and chemistry.

From this reality, a task was planned to introduce these students more efficiently in the course. In part of another research project, a software was 
developed to monitor the productive arrangement, observing enterprises inside productive arrangement links - SIMAP. The model was created to evaluate the enterprises in seven different ways. Carmo et al (2011) see that these ways are studied in industrial engineering courses. So, if students understand these concepts as soon as they get in the course, it is easier to motivate this group. Table 1 shows the proposed work.

Table 1 - Step-by-step Activity.

1. Access the website www.ot.ufc.br and study the SIMAP concepts using the wiki tool proposed (http://www.ot.ufc.br/mediawiki/index.php/Ferramentas do SIMAP). Discuss all questions about these concepts to construct a complete idea understood by the classroom.

2. Students must be organized in groups of five. The activity consists in evaluating a productive arrangement using the Productive Arrangement Monitoring System - SIMAP. To get this goal, they must follow some steps:

a) Choose a Productive Arrangement inside the University action area. For example: Lime industry, Salt industry, Fruit industry, etc.

b) Map the chosen productive arrangement and identify the links. A model is available in the website: www.ot.ufc.br. The proposed structure must be posted in a blog to be discussed with the professor, specialists and other students.

c) Quantify the productive arrangement by relating each enterprise of the productive arrangement in the links identified.

d) Contact the enterprises and arrange a visit to get data applied to a questionnaire. It is available in the same website.

e) After the data has been collected, upload this information inside the system and generate the graphs.

f) Analysis must be done with the graphs and the class work must be taken to the professor.

The difficulty in this process is because students do not know the concepts of industrial engineering course. First, a professor performed a preliminary course program analysis and he could observe many complex concepts difficult to be observed in Industrial Engineer professional life. This information was confirmed by the graph presented in Figure 3. The difficulty is such that they must pay much attention to the professor because it can create demoralization and de-motivation in the students. 


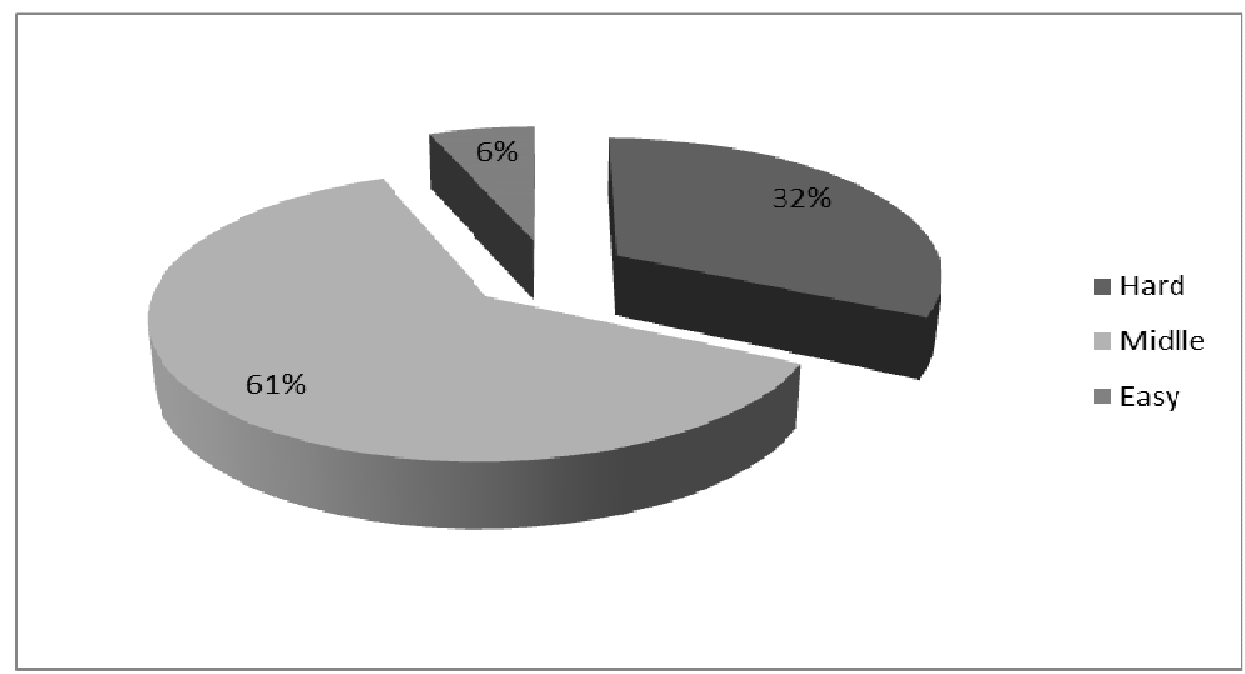

Figure 3 - How difficult are classroom topics?

To solve this problem, the SIMAP wiki tool was developed to help students understand the necessary concepts. In this point, it can be observed the first aspect of collaboration. When we use the wiki tool, the students can understand the concepts that were posted there. The first text construction was done by professors and some specialists. Of course, some concepts are not easy to be understood but the wiki allows students to relate their difficulties about the concepts and their application in their class work. These difficulties were answered by the professors or other students. It can be compared to a scaffolding teaching model, but it is better because not only the instructor interacts with students, but other students do it too. Accordingly, we can get a good material to be used in the next semester course. It is the first space of interaction inside the course, where all participants can help to construct a text to help them in their homework. Figure 4 shows the wiki developed by a researcher from laboratory of the university.

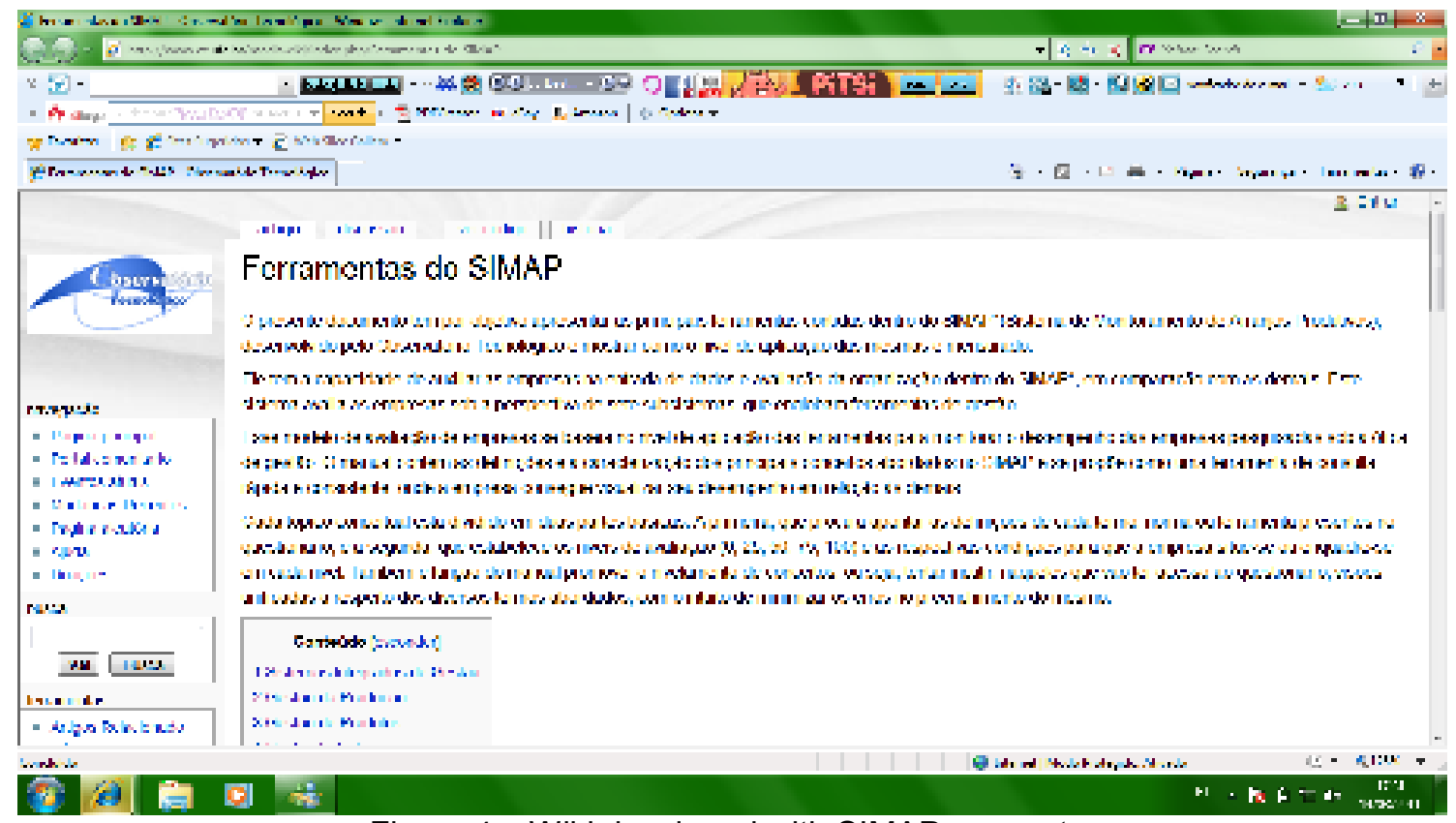

Figure 4 - Wiki developed with SIMAP concepts. 
These first objectives make students understand the first concepts. In this case, we can see that the student could get a more active position in the learning process because they have the responsibility to research and discuss the concepts on the internet. When they have some doubts, they can ask or research and post the answer in the wiki. This answer could be seen by all students. This collaboration promotes a better interaction among students.

The greatest benefit to the professor was that he/she could see the knowledge construction in the classroom during the semester. In this step, he/she had a more passive attitude and students had a more active one. The objective here consists of developing inside the students an autonomous learning with a small amount of the professor's actions in this process.

It was also asked how students look at the professor's performance in teaching the topics. Students like the way the professor teaches the topics and $26 \%$ classified it as excellent, $48 \%$ as good and $26 \%$ as regular. It also could be observed that $77 \%$ of the students fell motivated with the classes. But, as we could observe, $23 \%$ who do not fell motivated in discussion. Then, how to motivate this group? Looking at this, the professor thought of using a methodology with more practice with students and they were organized in five groups. They had to prepare the first part of their work and present it in classroom.

Each group chooses a productive arrangement and starts mapping the production process and the visits. The visits were thought by the students to understand the importance of the industrial engineer in productive arrangement and see where they would work when they graduate. These activities were developed according to the concept of Four Domain Development Diagram, looking to promote the students' motivation.

This activity was proposed because they could develop the three constructs posed by Vanasupa et al (2009). The first one, interest, the student can do his work like a practical work, having a good contact with enterprises. The second, value, he/she can observe how the concepts that will be studied during the course are important to his professional practice. The third one, autonomy, he/she can go further to get more information about the concepts before the specific course in Industrial Engineering course.

To promote the interaction, a space to discuss their work more specifically must be created. Firstly, it was proposed the works presentation to begin the discussion. The problem was that the students were afraid of the professor's and the other groups' opinion. They feared being criticized.

The professor recorded big problems in his daily-diary: low students' participation in the discussion about their works. The students did not begin any discussion and the professor had to do this. This hypothesis was confirmed when it was asked to students for collaboration, shown in Figures 5 and 6. 


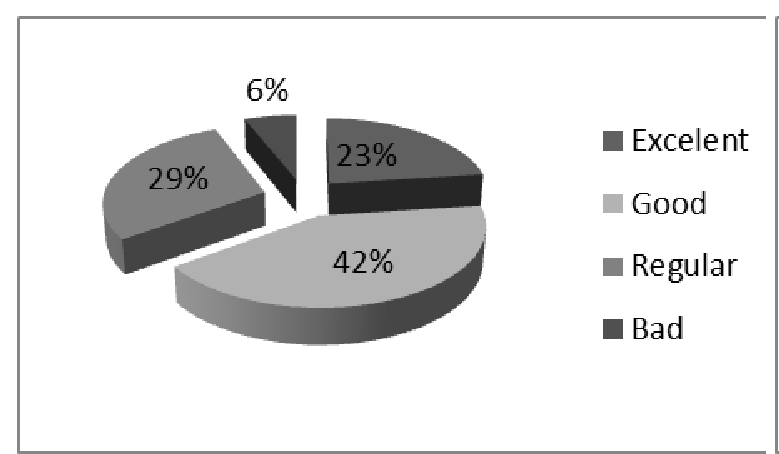

Figure 5 - How do you consider the information interchange inside your group?

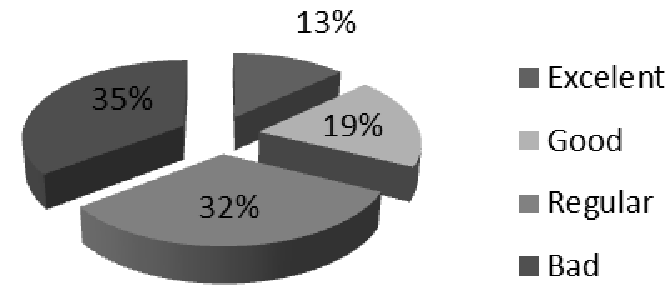

Figure 6 - How do you consider the information interchange among groups?

It can be observed that the information interchange inside the group happened, but it was not good. Regarding the information interchange among groups, that virtually did not happened. Looking at this point, the professor suggested students to use the blog to promote this interchange.

Because of this problem, a blog was created, in which student's actions and texts could be available to the professor and other groups. The blog was developed by the professor using "BlogSpot" (Google mechanism to create blogs) and all primary work was posted to be discussed. This blog was thought to be based on the cooperation concept, and all works were available to students. The URL to access the blog is: http://apufersa.blogspot.com. Figure 7 shows the blog developed.

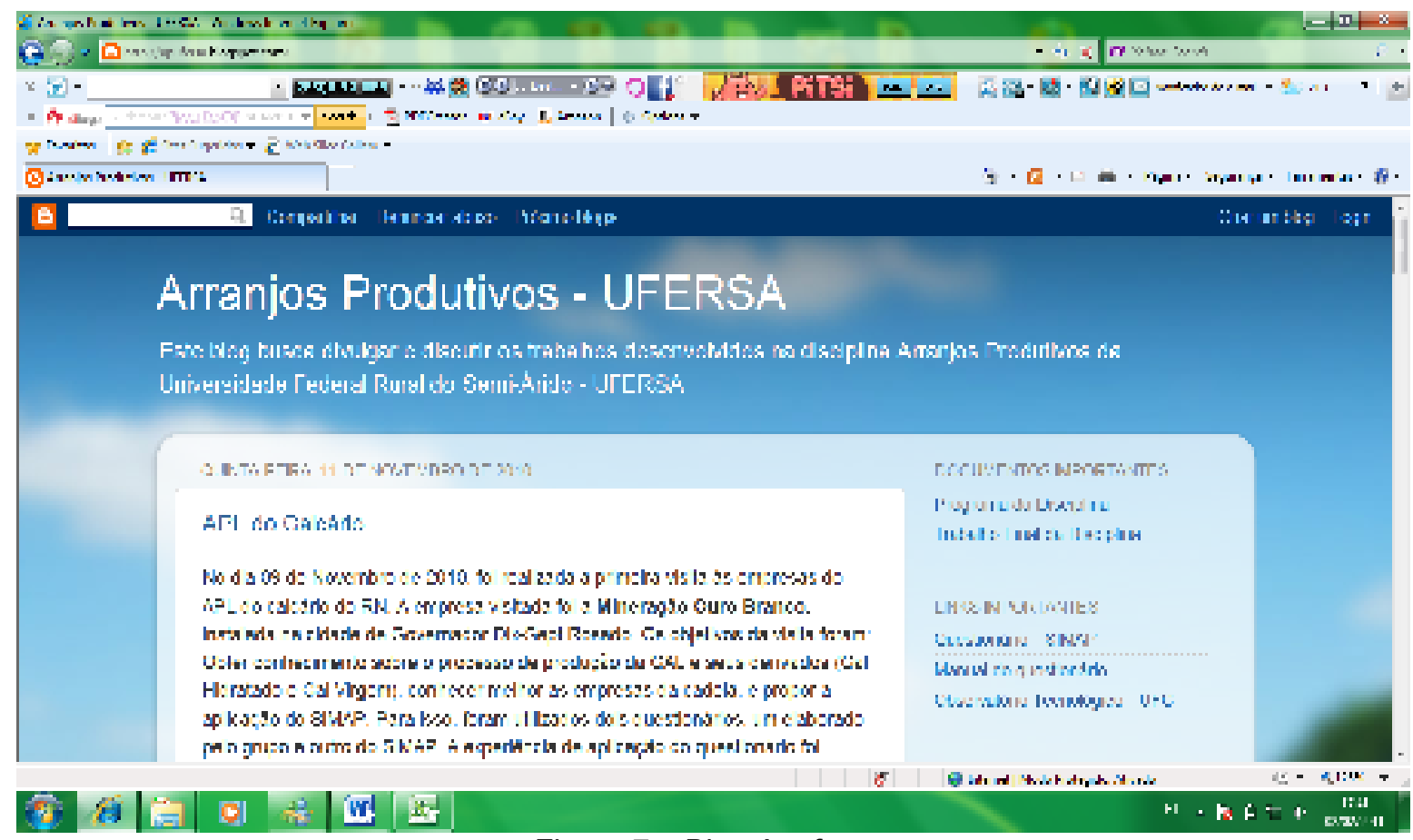

Figure 7 - Blog Apufersa.

The idea was to socialize the students' discoveries and share groups experiences. The visits, works, links with material and other information can be posted and accessed by the course components. It was also observed that other universities accessed the blog to see what has been being developed. 
Before the blog creation, students were asked about their motivation to use this resource. They were taught to have big interest in reading and commenting about the other groups' works, but they felt intimidated and the blog would help them about this problem. This information was confirmed by graphs in Figure 8 and 9 .

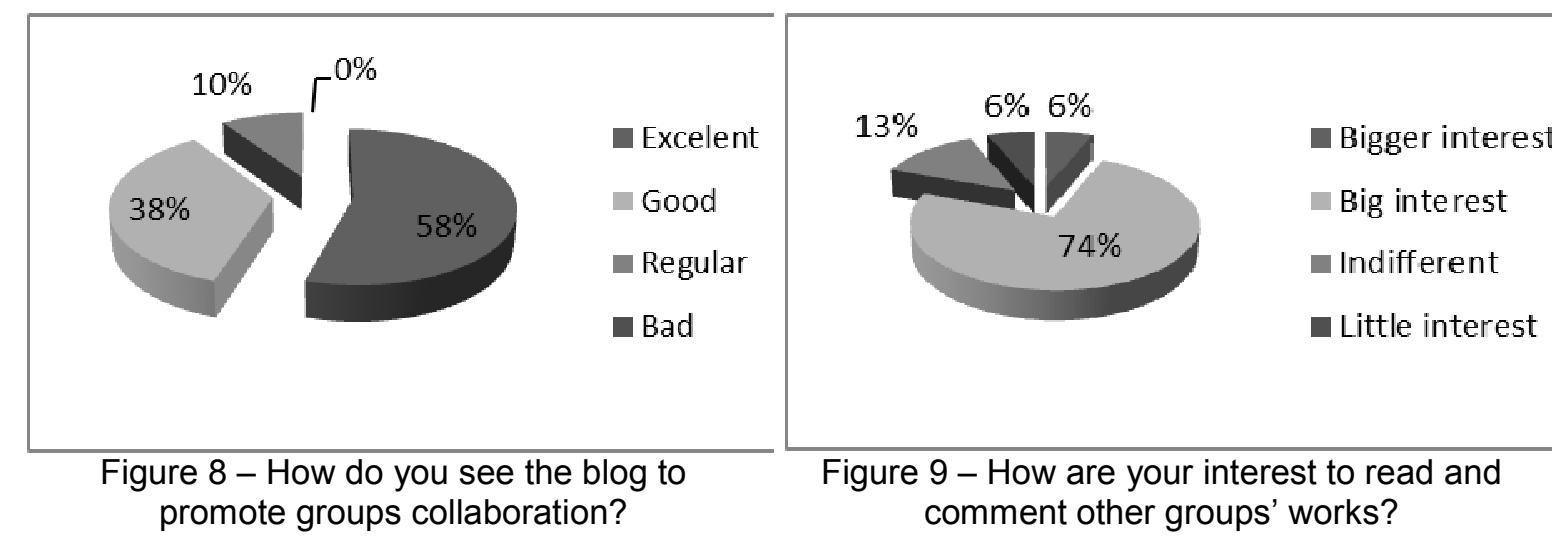

In the professors' diary, it could be observed some questions and comments by students, like: "Professor, when will the blog be available? I want read and post comments..."

In this blog, all students' works were posted to give a direction for the final works to be presented. The professor could follow it by accessing the blog statistics. We got more than 300 accesses from October to December. Figure 10 shows this aspect.

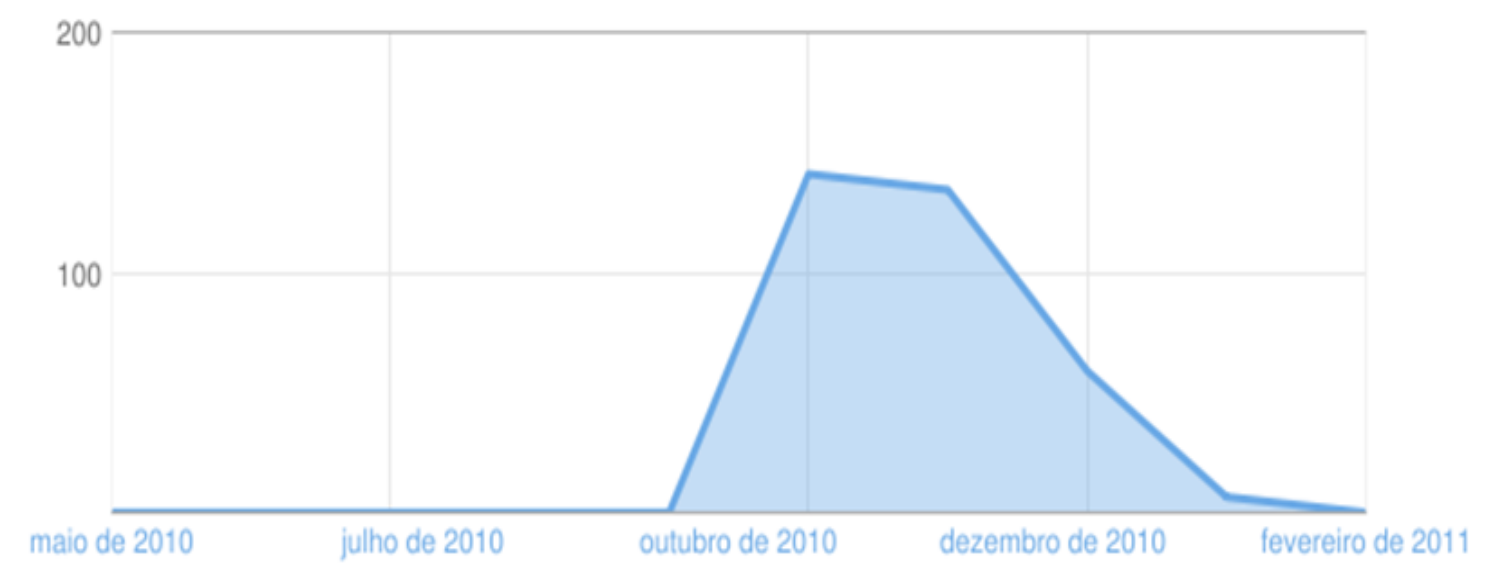

Figure 10 - Access Statistics.

An interesting fact is that the accesses were concentrated in the best three works of the course. All the students accessed the blog to get information to their works final versions. And they can see the good and bad points of each work, the final versions got better and they could learn from each other.

It can be observed that the professor had the initial active position when he/she presented the concepts. During the work development, many interactions happened among the groups. It is important to be pointed that they have, even with the blog, some intimidation and reluctance to write comments, but not when talking to 
other groups. The greatest benefit proposed by the blog was students' works socialization that allows a better work development, helping the knowledge development in the groups. So, this initiative was a successful experiment and will be done again in the next semester.

After the students used the blog, according to Figure 10, they were asked if this methodology helped their works development. The first aspect asked was to understand if the blog promoted a better cooperation inside and among groups. The graphs in Figures 11 and 12 show the students perceptions.

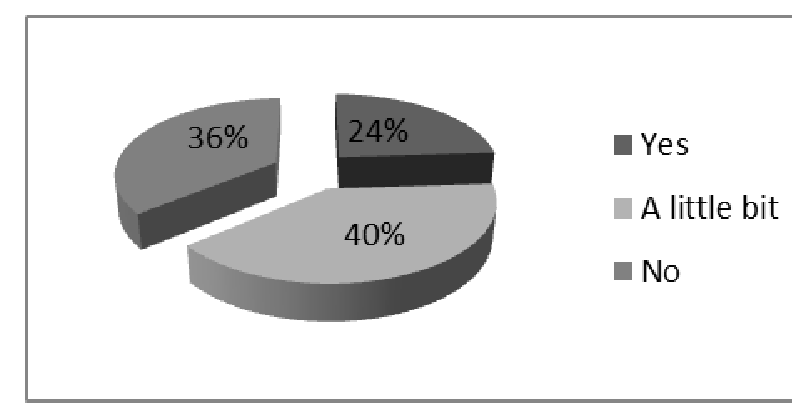

Figure 11 - Did the blog promote a better collaboration inside the group?

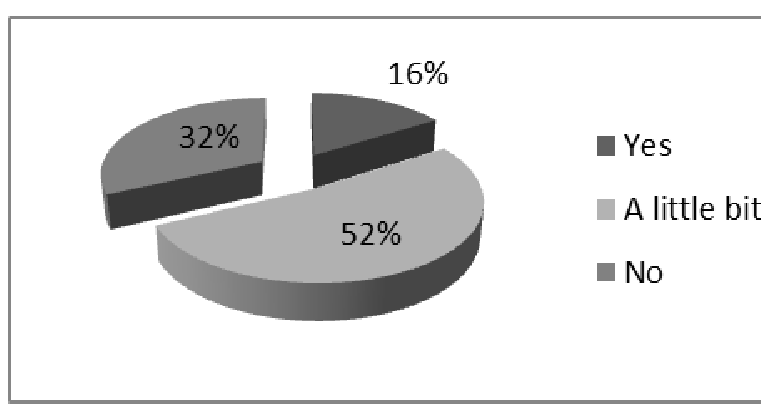

Figure 12 - Did the blog promote a better collaboration among groups?

It can be observed that the blog helped the students' work development, but only in part. This happened because only one blog functionally worked well. The blog was used like a portfolio for students' experiences and class works, but the interchange, collaboration and discussion were limited.

This happened because the classroom was formed by two different student types, the freshmen and end veterans. Moreover, there was not a confident atmosphere built that allows students to criticize each other's works. It is important to observe that these two groups have different knowledge levels. We only can conclude that the blog promoted the information socialization but not the discussion. Students pointed out the strong and weak links from this activity. Table 2 shows these points of views.

Table 2 - Testimonials about how the blog promoted collaboration.

\begin{tabular}{|l|l|}
\hline Strong links & Weak links \\
\hline$\bullet \quad$ "Material socialization, & $\bullet$ "Little collaboration among \\
facilitating the information flow"; & students"; \\
$\bullet \quad$ "We could see and understand & $\bullet \quad$ "There was not comments in \\
each group concepts application"; & the blog about students' works"; \\
$\bullet \quad$ "The theoretical knowledge was & \\
observed and associated to practice". & \\
\hline
\end{tabular}

Observing Figures 11 and 12, students testimonials in Table 1 and the professor's diary records, we can conclude that the blog was used in material socialization and did not work like a discussion space. On the other hand, $73 \%$ of the students considered that it promoted a better learning in relation to material socialization. 
Looking at the collaboration blog functionality, it could be observed that students did not have an active participation in the other group's work. The professor wanted to know why this happened. Students were asked about confidence in classroom. The result is presented in Figure 13. It was also asked if this had interfered their collaboration behavior. The result is presented in Figure 14.

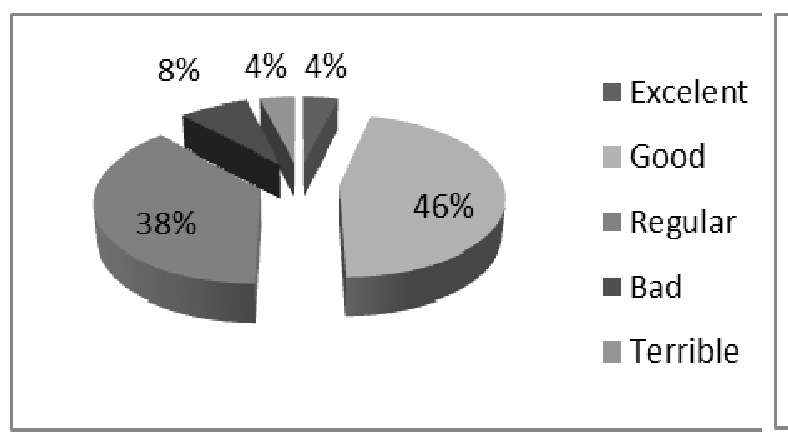

Figure 13 - How confident are you in classroom?

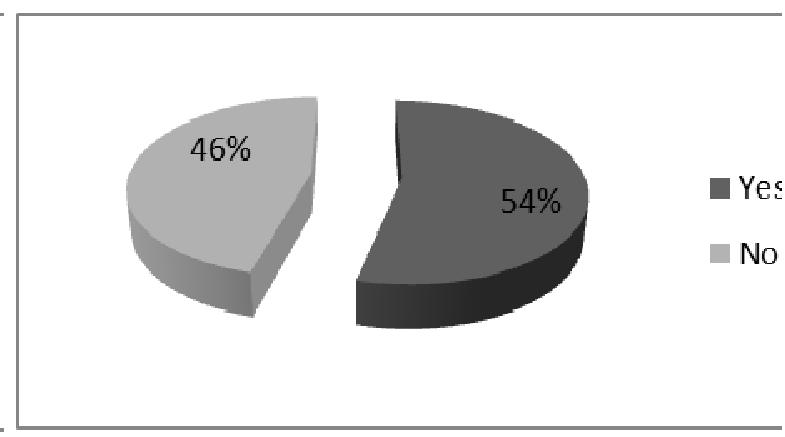

Figure 14 - Does diffidence interfere your collaboration attitude to other groups?

At this point, we can conclude that the diffidence interfere on the collaboration, being necessary that students know each other and have a previous contact. The results were confirmed in the professors' diary, being often pointed to when some students did not feel comfortable in their works socialization and feared criticism.

There was not strong relationship between students and this prejudiced the student's interaction during the work development. Despite this, students considered the activity proposed good to promote learning, which can be observed in Figure 15. Some considerations were also pointed out by students as related in Table 3 .

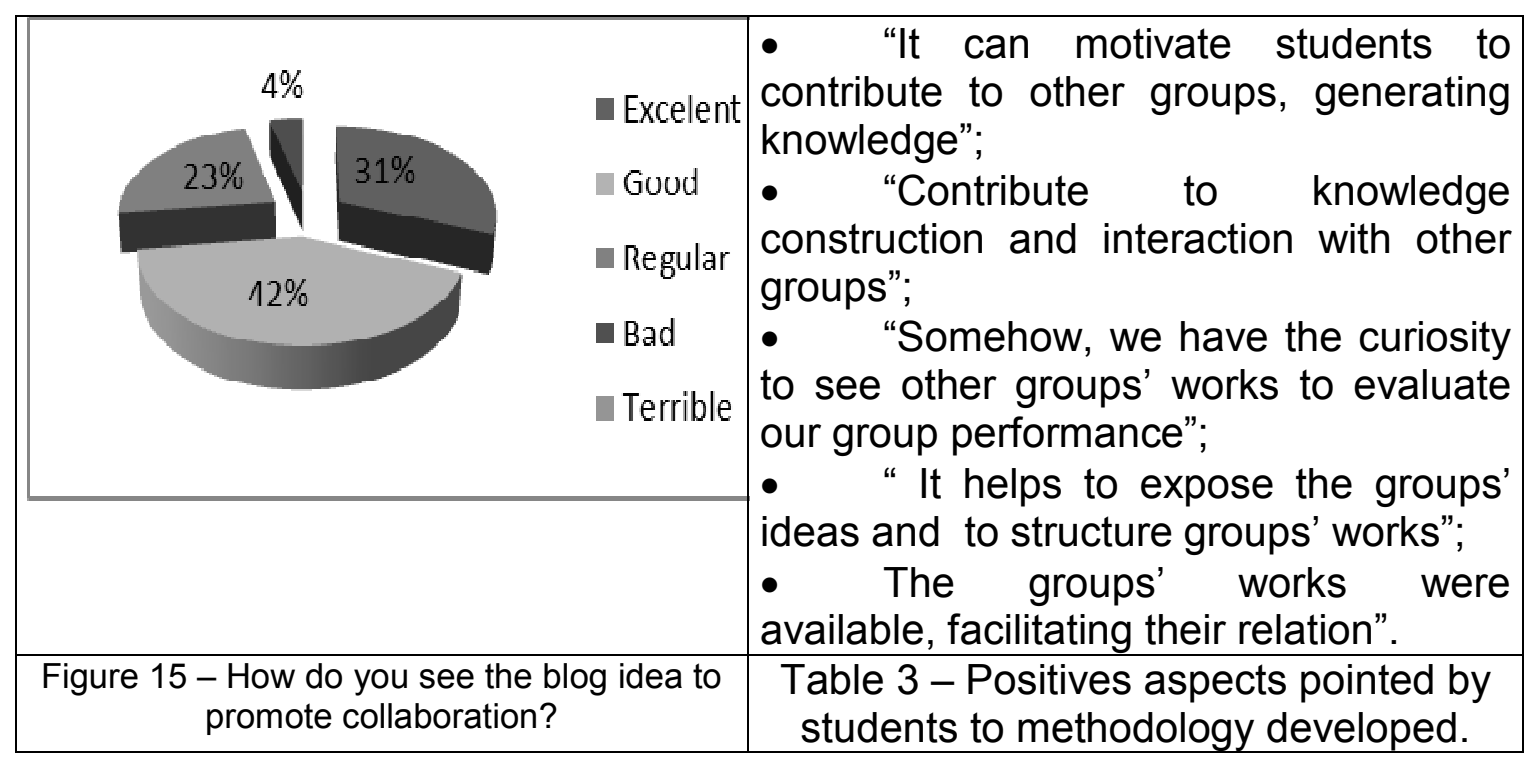

Despite the positive aspects pointed out by students, the professor could observe some limitations that students brought to him, as in the internet access. We also tried to observe how students see the blog influence in their works final version. 
So, students were asked about their expectations with the blog and work. Figures 16 and 17 present the results.

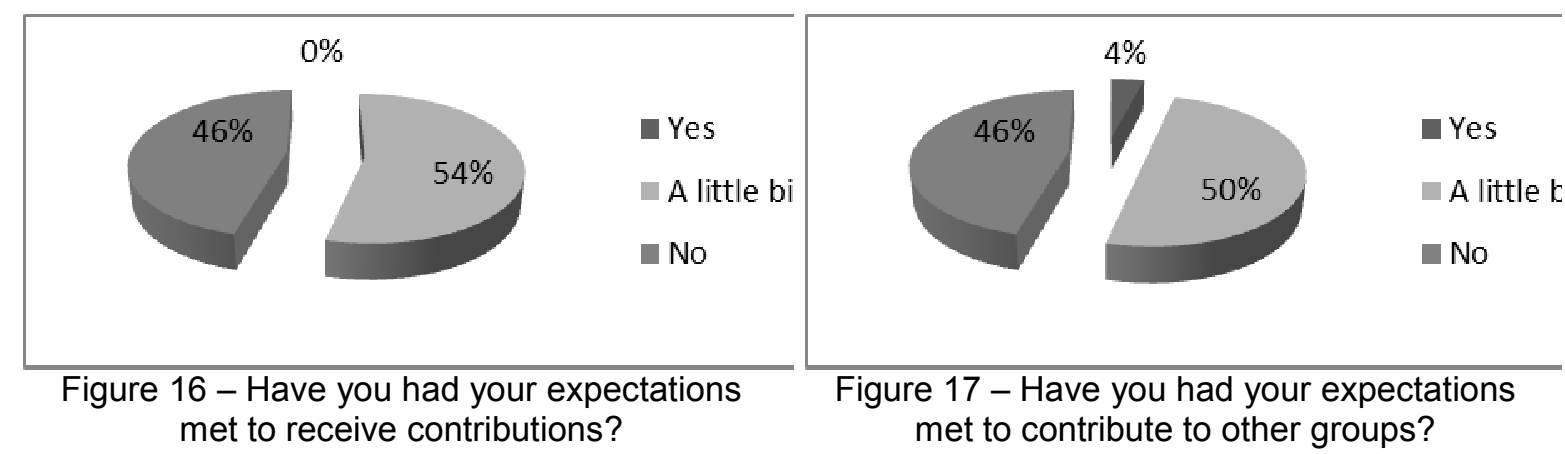

It could be observed that the blog did not get all of its functionalities, as it was thought in the work proposed by the professor. What really affected this activity was the lack of a confident relationship among students.

\section{CONCLUSIONS}

This paper discussed the use of information and communication technology tools integrated to active learning to promote interaction and facilitate the students learning. It is observed that interaction can be a rich space to learn. The problem with it consists in promoting activities that the students can interact with each other.

It can be concluded that this is not the only challenge and there is another one being relating to fear of criticism. The simple use of this group of tools does not guarantee the interaction and the concept behind it is more difficult to be understood by Professors. The traditional teaching model, focused in cognitive and psychomotor domains, is easier to be developed by Professors because they were trained to it. It is important to say that only this tool, if it is not thought inside an active activity, does not promote an active student position and the collaboration.

To achieve success in this experiment, two groups of tools were used. The first group is the technical tool, the SIMAP system. It is related to the interest and value constructs, to give a student the possibility to understand how he will get into the market. The second group, the wiki and blog, are related to the development of autonomy and interaction.

The use of wiki tool facilitated the collaborative learning and promotes the autonomous students' attitude creating discussion spaces. The use of blog tool placed students as active actors in the learning process because they could post their work and socialize the knowledge developed during the semester.

It is important to note the students' capacity using these tools, because they are familiarized and know how it works, facilitated and motivated them to learn using what they use normally to have fun. On the other hand, to have success in the activities using these tools, it is necessary Professors who know how to use them and when they are indicated. It is a challenge because many Professors were not normally trained to use this technology. 
If Professors do not use supports like those presented in this paper, it will be hard to promote active learning and collaboration activities. The bigger benefit is that this model can motivate students to go beyond the classroom and get more information outside of the university.

On the other hand, there are some challenges to be overcome like the Professors' training to use these tools and make them understand the learning concept behind these tools, i.e. the collaboration. Another challenge consists in developing strategies that ally collaboration and active learning concepts. Is not easy to establish these activities and it is necessary that Professors get some time developing it.

To conclude, we could observe that the tools used did not work as well in their functionalities, being a space to socialize knowledge but limited in discussion. The hypothesis to this result is because the classroom was formed by two different students group, creating a tense atmosphere, intimidating students from contributing to other group's works. It is necessary, in the next experience, to confirm this hypothesis when interviewing students.

Despite this fact, the experiences presented in this paper were successful because we could see that there is students' interest to use these tools and they can learn better when they are motivated, a fact obtained using SIMAP active work strategy allied with collaboration tools, like blog and wiki.

Even if they do not have all their functionalities explored, we able to motivate students to learn with other groups by reading the work posted in blog. This demonstrates that a blog has a big potentiality to be used in engineering classroom. Wiki can promote a space to help students to learn the initial concepts and improves autonomous learning.

\section{ACKNOWLEDGEMENTS}

Anibal Mascarenhas Filho as paper reviewer.

\section{REFERENCES}

CARMO, B. B. T.; ALBERTIN, M. R.; ARAGÃO, D. P.; DUTRA, N. G. S. Monitoring Methodology for Productive Arrangement (Supply Chain). In Kreowski, H. J.; ScholzReiter, B.; Thoben, K. D. Dynamics in Logistics. Springer Berlin Heidelberg, 2011.

CARVALHO, F. C. A. Tecnologias que educam: Ensinar e aprender com as tecnologias de informação e comunicação. São Paulo: Pearson Prentice Hall, 2010.

COUTINHO, C. P.; JUNIO, J. B. B. Blog e Wiki: os futuros professores e as ferramentas da Web. In: Marcelino, M. J.; Silva, M. J., org. - "SIIE'2007: Actas do Simpósio Internacional de Informática Educativa, v. 9. Porto, Portugal, 2007.

ESTES, A. C.; WELCH, R. W.; RESSLER, S. J. Teaching lessons learned. Journal of Professional Issues in Engineering Education \& Practice. New York, 2005. 
FLICK, U. Introdução à pesquisa qualitativa. Tradução Joice Elias Costa, $3^{\circ}$ ed. Porto Alegre: Artmed, 2009.

GOMES, M. J. Blogs: um recurso e uma estratégia pedagógica. In: Actas do VII Simpósio Internacional de Informática Educativa, Portugal: Leiria - 16-18 de Novembro de 2005.

HMELO-SILVER, C. E.; DUNCAN, R. G.; CHINN, C. A. Scaffolding and Achievement in Problem-Based and Inquiry Learning: A Response to Kirschner, Sweller, and Clark (2006). Educational Psychologist, v. 42(2), p. 99-107. Lawrence Erlbaum Associates, Inc., 2007.

LABRANCHE, D. F. Scaffolding-Getting Students Engaged in Learning. Journal of Professional Issues in Engineering Education and Practice - ASCE. April, 2006.

JOHNSON, P. A. Problem-based, cooperative learning in the engineering classroom. Journal of Professional Issues in Engineering Education and Practice. January, 1999.

HOLVIKIVI, J. Learning styles in engineering education: the quest to improve didactic practices. European Journal of Engineering Education. v. 32, n. 4, 2007.

NIRMALAKHANDAN, N.; RICKETTS, C.; MCSHANNON, J.; BARRETT, S. Teaching Tools to Promote Active Learning: Case Study. Journal of Professional Issues in Engineering Education and Practice - ASCE. January, 2007.

NETTO, C.; GRASSI, D.; ARUSIEVICZ, F.; TOINIDANDEL, I. Aprendizagem Colaborativa Apoiada por Computador. RENOTE. Revista Novas Tecnologias na Educação, CINTED - UFRGS, v. 2, n. 1, p.1-5, 2004.

NUNES, A. I. B. L.; SILVEIRA, R. N. Psicologia da Aprendizagem: processos, teorias e contextos. Fortaleza: Liber Livro, 2008.

PRIMO, A. F. T.; RECUERO, R. C. Hipertexto Cooperativo: Uma Análise da Escrita Coletiva a partir dos Blogs e da Wikipédia. Revista da FAMECOS, n. 23, 2003, p. 5463.

SANTAMARIA, F. G.; ABRAIRA, C. F. Wikis: posibilidades para el aprendizaje colaborativo em Educacion Superior. In: L. Panizo et. al (Eds.) Proceedings of the 8th International Symposium, 2006.

SCHWARTZ, L.; CLARK, S.; COSSARIN, M.; RUDOLPH, J. Educational Wikis: features and selection criteria. The International Journal of Research in Open and Distance Learning, v. 5, 2004.

THIRY-CHERQUES, H. R. In. VIEIRA, M. M. F.; ZOUAIN, D. M. Pesquisa qualitativa em administração. Rio de Janeiro: Editora FGV, 2006.

VANASUPA, L.; STOLK, J.; HERTER, R. J. The four-domain development diagram: a guide for holistic desing of effective learning experiences for the twenty-first century engineer. Journal of Engineering Education. Washington, 2009. 